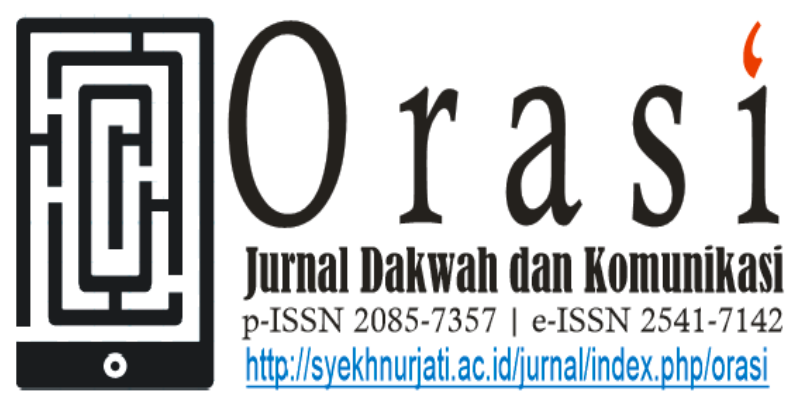

Volume 10 No. 2 Desember 2019

\title{
IKLIM KOMUNIKASI, IKLIM ORGANISASI DAN IKLIM KOMUNIKASI ORGANISASI
}

\section{COMMUNICATION CLIMATE, ORGANIZATION CLIMATE AND ORGANIZATIONAL COMMUNICATION CLIMATE}

\author{
Cartono $^{1}$, dan Asep Maulana ${ }^{2}$ \\ Program Studi Komunikasi Penyiaran Islam, IAIN Syekh Nurjati Cirebon \\ Ie-mail:cartonopr@gmail.com \\ 2 e-mail: maulanasunankalijaga@gmail.com
}

\begin{abstract}
ABSTRAK
Adanya sebuah observasi tentang sebuah organisasi agar dapat mengetahui segala bentuk komunikasi yang ada didalamnya. Kemajuan organisasi akan terus meningkat jika iklim komunikasinya baik. Di dalam organisasi iklim komunikasi memainkan peranan dalam mendorong anggota organisasinya untuk mencurahkan usaha atas setiap tugas yang dilakukan pengurus organisasi, dimana dengan adanya sistem kerja yang terkendali akan memberikan pengaruh positif terhadap iklim komunikasi dan sebaliknya. Berdasarkan hasil penelitian menunjukkan bahwa faktor kepercayaan pengurus, keakraban dan kerjasama diantara pengurus dalam memikirkan program UKM HTQ tersebut mempunyai pengaruh yang signifikan terhadap kinerja pengurus dalam merealisasikan program-program yang telah dibuat dan disepakati bersama. Kesimpulannya bahwasannya iklim organisasi memang tak senantiasa sesuai apa yang diharapkan, namun dengan adanya kerjasama dan dorongan dari ketua umum dan pembina mampu memberikan kontribusi yang positif terhadap kinerja pengurus dalam merealisasikan programnya.
\end{abstract}

Kata Kunci: Iklim, Komunikasi, Organisasi

\section{ABSTRACT}

There is an observation about an organization in order to know all forms of communication that is in it. The progress of the organization will continue to increase if the communication climate is good. Within the organization the communication climate plays a role in encouraging members of the organization 
to devote effort to each task carried out by the organization's management, where a controlled work system will have a positive influence on the communication climate and vice versa. Based on the results of the study showed that the trust factors of the management, familiarity and cooperation among the management in thinking of the HTQ UKM program had a significant influence on the performance of the management in realizing the programs that had been made and agreed upon. The conclusion is that the organizational climate does not always match what is expected, but with the cooperation with encouragement from the general chairperson and the coach is able to make a positive contribution to the performance of the board in realizing the program.

Keywords: Climate, Communication, Organization

\section{Pendahuluan}

Komunikasi adalah proses dinamis dan melibatkan tekhnik komunikasi yang kompleks, jaringan dan saluran. Ini tidak hanya melibatkan ke atas dan ke bawah komunikasi, tetapi manajer dan karyawan berkomunikasi satu sama lain dalam berbagai cara pada tingkat yang berbeda (Ali, A Haider, 2012). Organisasi bisa terbentuk dengan adanya sebuah komunikasi. Tanpa komunikasi tidak mungkin ada sistem sosial atau organisasi. Komunikasi dapat berlangsung sebagai pengintegrasian unsur-unsur yang menjadikan sebuah komponen sistem yang dinamis. Seperti yang dijelaskan (Yarosca 2016) bahwa organisasi tidak akan bertahan jika tidak terjalin komunikasi yang baik antara atasan dan bawahan. Dengan adanya komunikasi dalam organisasi akan membuat hubungan yang baik antara atasan dan bawahan. Jika hubungan antara atasan dan bawahan baik maka akan menimbulkan hal yang baik dan sebaliknya. Organisasi itu merupakan sistem yang terbuka, menciptakan sebuah komunikasi antara satu sama lain untuk bertukar pesan dengan anggotanya.
Komunikasi dalam organisasi juga berfungsi sebagai penyampaian pesan, ide-ide dan informasi supaya mendapatkan timbal balik untuk mencapai sebuah tujuan yang sudah diterapkan (Rahmawati and Sutarso 2017).

Dalam penelitian ini, penulis meneliti Unit Kegiatan Mahasiswa Hai'ah At-Tahfidz Wal-Qira'ah, UKM ini merupakan satu-satunya Unit kegiatan mahasiswa yang bergelut dan terfokus di bidang ke Al-Qur'anan di IAIN Syekh Nurjati Cirebon. Dan mendapat banyak respon postif baik dari mahasiswa maupun dosen.

Peneliti merumuskan masalah penelitian mengenai iklim organisasi Unit Kegiatan Mahasiswa Hai'ah At-Tahfidz Wal-Qira'ah (UKM HTQ), dan tujuan dalam penelitian ini adalah untuk mengetahui bagaimana iklim organisasi dalam melaksanakan fungsi dan mencapai tujuan Unit Hai'ah At-TahfidzWal-Qira'ah.

\section{Iklim Komunikasi}

Istilah "iklim" di sini merupakan kiasan (metafora) "Iklim komunikasi organisasi" menggambarkan suatu kiasan bagi iklim fisik. 
Sama seperti cuaca membentuk iklim fisik untuk suatu kawasan, Cara orang bereaksi terhadap aspek organisasi menciptakan suatu iklim komunikasi. Iklim komunikasi, di pihak lain, merupakan gabungan dari persepsi-persepsi - suatu evaluasi makromengenai peristiwa komunikasi, perilaku manusia, respons pegawai terhadap pegawai lainnya, harapan-harapan, konflik- konflik antarpersona, dan kesempatan bagi pertumbuhan dalam organisasi tersebut. iklim komunikasi berbeda dengan iklim organisasi dalam arti iklim komunikasi meliputi persepsi-persepsi mengenai pesan dan peristiwa yang berhubungan dengan pesan yang terjadi dalam organisasi. Iklim komunikasi organisasi terdiri dari persepsi-persepsi atas unsur-unsur organisasi dan pengaruh unsur-unsur tersebut terhadap komunikasi. Pengaruh ini didefinisikan, disepakati, dikembangkan dan dikokohkan secara berkesinambungan melalui interaksi dengan anggota organisasi lainnya. Pengaruh ini menghasilkan pedoman bagi keputusankeputusan dan tindakan-tindakan individu, dan mempengaruhi pesan- pesan mengenai organisasi.

Suatu iklim komunikasi berkembang dalam konteks organisasi. Unsur-unsur dasar yang membentuk suatu organisasi dapat diringkaskan menjadi 5 kategori besar: anggota organisasi, pekerjaan dalam organisasi, praktik-praktik pengelolaan, struktur organisasi, dan pedoman organisasi.

\subsection{Pengaruh Komunikasi}

Iklim komunikasi merupakan fungsi kegiatan yang terdapat dalam organisasi untuk menunjukkan kepada anggota organisasi bahwa anggota organisasi tersebut mempercayai mereka dan memberi mereka kebebasan dalam mengambil resiko; mendorong mereka dan memberi mereka tanggung jawab dalam menjalankan tugas-tugas mereka; menyediakan informasi yang terbuka dan cukup tentang organisasi; Mendengarkan dengan penuh perhatian serta memperoleh informasi yang dapat dipercayai dan terus terang dari anggota organisasi; secara aktif memberi penyuluhan kepada para anggota organisasi sehingga mereka dapat melihat bahwa keterlibatan mereka penting bagi keputusan- keputusan dalam organisasi; dan menaruh perhatian pada pekerjaan yang bermutu tinggi dan memberi tantangan (Pace and Faules2006).

Para anggota organisasi menentukan dan meneguhkan eksistensi pengaruh komunikasi. Jadi, melalui proses interaksi, para anggota organisasi menerima eksistensi kepercayaan, dukungan, keterbukaan, penyuluhan, perhatian dan keterusterangan. Dengan demikian, pengaruh komunikasi dapat bermacam-macam dan berubah menurut cara-cara pengaruh komunikasi ini ditentukan dan diteguhkan melalui interaksi di antara para anggota organisasi.

Pengaruh-pengaruh komunikasi bergabung dalam beberapa cara yang berbeda untuk mengembangkan suatu kepercayaan dan 
sistem nilai yang dikenali oleh anggota organisasi sebagai iklim organisasi. Setiap iklim dapat ditandai dengan gabungan yang berbeda dari pengaruh- pengaruh komunikasi sehingga iklim tersebut dapat disebut dengan berbagai nama yang berlainan, seperti keikutsertaan, acuh tak acuh, mendukung, bermusuhan, menghidupkan, bertahan, positif, atau negatif.

Iklim komunikasi tertentu memberi pedoman bagi keputusan dan perilaku individu. Keputusan-keputusan yang diambil oleh anggota organisasi untuk melaksanakan pekerjaan mereka secara efektif, untuk mengikatkan diri mereka dengan organisasi (Guzley, 1992), iklim komunikasi dapat menjadi pengaruh yang paling penting dalam produktivitas organisasi, karena iklim mempengaruhi usaha anggota organisasi. Usaha dalam hal ini merujuk kepada penggunaan tubuh secara fisik dalam bentuk mengangkat, berbicara, atau berjalan, dan penggunaan mental dalam bentuk berpikir, menganalida, dan memecahkan masalah (Frantz, 1988,hlm.74-77).

Usaha biasanya terdiri atas empat unsur: "(1) aktivitas (A) yang merupakan pekerjaan tersebut; (2) langkah-langkah (L) pelaksanaan kerja; kualitas (k) hasil; dan pola waktu (W) kerja" (frantz, 1988, hlm 75). Anggota organisasi memilih berbagai jumlah usaha yang mereka curahkan untuk kegiatan organisasi, langkah-langkah pelaksanaan kerja, perhatian terhadap pekerjaan mereka, kualitas hasil kerja mereka dan jumlah waktu yang mereka berikan kepada pekerjaan mereka.
Mereka membuat pilihan-pilihan ini karena "usaha-usaha yang diarahkan" usaha yang kami rujuk tidak secara langsung dibayar sebagai bagian dari perjanjian untuk tenaga kerja dalam organisasi, tetapi menggambarkan hasil respons Anggota organisasi atas motivasi-motivasi yang diberikan oleh kejiwaan mereka dan/ oleh lingkungan eksternal tempat mereka bekerja (frantz, 1988,hlm 74). Berdasarkan pandangan kami, motivasi- motivasi ini terutama berasal dari pemahaman seseorang mengenai iklim komunikasi suatu organisasi. Jadi, iklim komunikasi memainkan peranan sentral dalam mendorong anggota-anggota organisasi untuk mencurahkan usaha kepada pekerjaan mereka dalam organisasi.

Kesediaan untuk melakukan usaha sungguh-sungguh atas nama organisasi adalah satu dari tiga faktor komitmen organisasi (Mowday, steers dan Potter, 1979, hlm. 226). Kepercayaan yang kuat serta penerimaan atas tujuan serta nilai-nilai organisasi, dan keinginan yang besar untuk mempertahankan keanggotaan dalam organisasi adalah dua faktor komitmen organisasi lainnya. Dalam penelitian Guzley (1992), pastisipasi (suatu dimensi iklim organisasi) timbul sebagai suatu penduga atas komitmen bagi pengawal dengan masa kerja lima tahun atau lebih dalam organisasi tsrsebut. Pertimbangan Guzley adalah pastisipasi besar sekali artinya bagi pekerja yang telah membentuk kesadaran pengendalian (sense of control) atas situasi kerja mereka, yang baru muncul setelah mereka mencapai suatu masa kerja kerja 
tertentu dalam organisasi tersebut.

Bila kesadaran pengendalian dan penerimaan sudah terbentuk, kebutuhan pegawai untuk merasa bahwa komunikasi komunikasi mereka ada pengaruhnya menjadi penting. Kenyataannya, tanpa perasaan mengenai adanya pengaruh semacam ini, pegawai dapat smenjadi tidak puas dan meninggalkan organisasinya; artinya, komitmen organisasi mereka mungkin akan menurun" (hlm.397) Jadi, dapat kita simpulkan bahwa iklim komunikasi dalam organisasi mempunyai konsekuensi penting bagi pergantian dan masa kerja pegawai dalam organisasi. Iklim komunikasi yang positif cenderung meningkatkan dan mendukung komitmen pada organisasi.

Sebaliknya, sebagai suatu fenomena interaktif, perubahan- perubahan dalam suatu sistem kerja atau organisasi dapat berpengaruh positif pada persepsi atas iklim komunikasi dalam suatu organisas. Misalnya, pelaksanaan program pelatihan, tim-tim kerja pengarah diri, program-program mentoring, majalah-majalah khusus, dan simbol-simbol organisasi dapat mempengaruhi persepsi mengenai bagaimana organisasi menunjukan kepercayaan, kejujuran atau penyuluhan. Tim kerja pengarahan diri (self-directed team) tampaknya memiliki berbagai pengaruh baik dalam organisasi, meliputi peningkatan usaha dan produktivitas kerja, tetapi hal yang paling nyata adalah pembentukan dan pemeliharaan persepsi yang positif atas organisasi.

Proses-proses interaksi yang terlibat dalam perkembangan iklim komunikasi organisasi juga memberi andil pada beberapa pengaruh kembali unsur-unsur dasar organisasi. Iklim komunikasi yang kuat dan organisasi yang lebih mendukung. Penggunaan mekanisme untuk meningkatkan iklim, kenyataanya tidak sekadar mempengaruhi iklim, melainkan menyebabkan perubahan mendasar yang lebih banyak dalam proses-proses mendasar yang membentuk bahan dan subtansiorganisasi.

Hal itu sangat mungkin, misalnya, bagi tim-tim kerja pengarahan diri agar menghasilkan perubahan dalam acara pelaksanaan kerja dalam suatu organisasi dan dalam cara anggota organisasi dibimbing untuk memperlancar iklim yang lebih positif. Di pihak lain, proses-proses yang terlibat memperkirakan bahwa mekanisme berpengaruh timbal balik terhadap persepsi dan unsur-unsur dasar organisasi yang memungkinkan perubahan pada salah satu atau kedua-duanya menghasilkan perubahan dalam iklim, atau perubahan iklim menghasilkan perubahan dalam implementasi mekanisme dan unsur-unsur dasar organisasi (Pace and Faules 2018).

\subsection{Iklim Organisasi}

Iklim organisasi adalah iklim manusia di dalam, dimana para anggota organisasi melakukan pekerjaan mereka. Iklim organisasi merupakan sebuah konsep yang menggambarkan suasana internal lingkungan organisasi yang dirasakan anggotanya selama mereka beraktivitas dalam rangka tercapainya tujuan organisasi (Keith and Newstorm 2000) 


\subsection{Iklim Komunikasi Organisasi}

Iklim komunikasi organisasi merupakan suatu citra makro, abstrak dan gabungan dari suatu fenomena global yang disebut komunikasi organisasi. Kita mengasumsikan bahwa iklim berkembang dari interaksi antara sifat-sifat atau organisasi dan persepsi individu atas sifat-sifat itu. Iklim dipandang sebagai suatu kualitas pengalaman subjectif yang berasal dari persepsi atas karakter-karakter yang relative langgeng pada organisasi (Falcione et al., 1987,hlm.198, 203).

Tiaguri (1968) mengatakan bahwa iklim organisasi adalah kualitas yang relative abadi dari lingkungan internal organisasi yang dialami oleh anggota-anggotanya, mempengaruhi tingkah laku mereka serta dapat diuraikan dalam istilah nilai-nilai suatu karakteristik tertentu dari lingkungan.

$$
\text { Komunikasi internal sangat }
$$

berhubungan dengan kenyamanan iklim komunikasi dan ilklim organisasi di dalam suatu organisasi. Ouchi (1981), peters dan Waterman (1982), dan Deals dan Kennedy (1962) dalam Jurnal Does Organizatonal Culture Mediate The Relationship Between Tranformational Leadership and Organizational Communitment mengungkapkan mengenai hubungan antara budaya organisasi dan komitmen organisasi secara teoritis sebagai berikut: "Organizational culture affects a range of organizational and individual outcomers incluiding productivity, performance, commitment, and self-confidence."

Keberlangsungan hidup suatu organisasi tidak dapat terlepas dari iklim dalam organisasi, yang menggambarkan adanya suasana yang ada dalam organisasi. Dalam menggambarkan suasana dalam organisasi dapat dilihat dari iklim organisasi dan iklim komunikasi yang ada dalam organisasi.

Deddy Mulyana menawarkan lingkup kajian komunikasi organisasi bahwa komunikasi organisasi terjadi dalam suatu jaringan yang lebih besar daripada komunikasi kelompok. Komunikasi organisasi seringkali melibatkan komunikasi antar pribadi da nada kalanya juga komunikasi public. Komunikasi formal adalah komunikasi menurut struktur organisasi, yaitu komunikasi kebawah, komunikasi keatas dan komunikasi horizontal, sedangkan komunikasi informal tidak bergantung pada struktur organisasi, seperti komunikasi antar sejawat, juga termasuk gossip (Hapsari and Arifin 2016).

\section{Profil UKM HTQ}

Hai'ah At-Tahfidz Wal-Qira'ah adalah adalah unit kegiatan mahasiswa sebagai formasi penggugah semangat tahfidz dan qira'ah di lingkungan Institut Agama Islam Negeri (IAIN Syekh Nurjati Cirebon). Organisasi ini didirikan pada hari Ahad tanggal 25 September 2011 dan masih berdiri hingga saat ini, UKM ini merupakan inisiatif kreatif-inovatif guna menunjang Al-Qur'an penguasaan dan pengaplikasian keilmuan islam sebagai bentuk uji kelayakan kompetensi dalam kehidupan beragama, berbudi luhur, berbangsa dan bernegara. Hai'ah At-Tahfidz 
Wal-Qira'ah senantiasa memperjuangkan dan menumbuh kembangkang tahfidz ta'lim-ta'lim keilmuan serta nilai-nilai otentik Al-Qur'an-hadits dalam kehidupan dan kebudayaan. Yang berdasarkan nilai-nilai qur'ani dan khazanah keilmuan yang berasaskan pada Al-Qur'an, Hadits, Ijma Ulama, dan Qiyas.

\section{Metode Penelitian}

Penelitian ini menggunakan metode observasi dan wawancara, metode observasi merupakan penelitian yang tidak memberikan perlakuan apapun kepada responden, hanya mengumpulkan data menggunakan instrument yang telah dibekukan, seperti angket, tes dan lain sebagainya. Sedangkan metode wawancara merupakan suatu proses yang mengharuskan penafsiran dan penyesuaian terus menrus. Wawancara adalah salah satu cara untuk mencari fakta dengan meminjam indera (mengingat badan merekontruksi sebuah peristiwa, mengutip pendapat dan opini narasumber. Kunci wawancara yang baik, kata mike fancher, wartawan Seattle Times," adalah kemungkinan narsuber mengatakan apa yang sebenarnya difikirkan, bukan memikirkan apa yang mau dikatakan (Kusumaningrat and Kusumaningrat 2017).

\section{Hasil Dan Pembahasan}

Berdasarkan hasil dari wawancara dengan ketua umum Unit Kegiatan Mahasiswa Hai'ah At-Tahfidz Wal-Qira'ah kang Ade Faturrahman bahwasannya kondisi iklim komunikasi di UKM nya tersebut sudah bisa dibilang stabil dari tahun-tahun belakangan. Biasanya dalam komunikasi terjadi ketika kurang berkoordinasi antara satu pengurus dengan pengurus lainnya. Hal ini sebabkan karena berbagai kesibukan yang berbeda-beda dan kurangnyakedisiplinan.

Para pengurus selalu menjalankan programnya dengan bekerja sama, mulai dari divisi kajian, divisi ilmu komunikasi dan tekhnologi, divisi seni qur'ani, divisi keorganisasian dan kaderisasi, divisi tahfidz dan tasmi' dan divisi Enterpreneurship. Meskipun memang tidak semua program terealisasi dan ketika kajianpun 50\% yang hadir di kajian tersebut. Karena waktu kajian yang terkadang bentrok dengan waktu kuliah membuat peserta kajian tidak banyak yang hadir.

Hubungan antar demisioner dari angkatan pertama pada 2011 sampai saat ini tidak semuanya terjalin baik, karena beberapa kesibukan beberapa demisioner, sehingga hanya beberapa demisioner yang masih dapat terkoneksi keberadaannya baik kabar, maupun aktivitasnya saat ini.

Kualitas dari anggota HTQ sendiri berbeda-beda, ketika ada salah satu anak yang mempunyai kemampuan lebih dan mampu membina anggota dibidang Tahsin Qiro'ah maka ini menjadi salah satu wadah untuk anggota yang lainnya belajar, apalagi saat ini tahsin sedang eksis dikalangan mahasiswa, karena lumayan banyak peminatnya. Sehingga setiap tahun UKM ini selalu bertambah anggotanya.

Hubungan antar ketua umum dan 
anggota nya pun sangat baik. Sehingga tak jarang sekretariat tempat UKM ini dijadikan sebagai rumah kedua bagi anggota maupun pengurus. Hal ini menjadi salah satu kekeluargaan di HTQ begitu terasa. Segala persepsi yang berbeda antar anggota dan pengurus seakan bukan lagi menjadi tembok pemisah karena bagi mereka kenyamanan dalam jalinan keluarga lebih penting, perbedaan ada biasanya ketika berada dalam forum diskusi terkait hal program kegiatan yang akan dilaksakan namun semua itu akhirnya akan memberikan keputusan hasil bersama.

Melalui program-program dalam setiap kegiatan yang dilakukan UKM HTQ sendiri adalah salah satu cara untuk membuat iklim komunikasi organisasi terjalin dengan baik, dengan banyaknya waktu bersama maka komunikasi antar satu dengan yang lainnya akan semakin baik. Setiap akan ada Musyawarah atau setiap ada kegiatan biasanya para pengurus maupun anggota sowan (berkunjung) ke pembinanya, meminta arahan maupun masukan dari beliau untuk kesuksesan acara yang akan dilaksanakan.

Iklim organisasi merupakan sesuatu yang nyata dirasakan oleh semua pengurus dalam kinerjanya, sehingga apa yang dirasakan itu mempengaruhi perilakunya yang akhirnya akan menentukan tingkat produktivitas program kerja mereka. Produktivitas pengurus sangat terkait dengan struktur yang ada yakni mengenai jobdes sesuai bagian yang ada, tanggung jawab pengurus terhadap programnya mulai dari kesadaran diri masing-masing maupun kelompok, komunikasi yang diciptakan dari ketua umum kepada pengurus maupun anggota, dan penghargaan untuk anggota maupun pengurus yang rajin dan ulet saat ada berbagai kegiatan tahunan.

Iklim organisasi yang terjalin dalam kepengurusan akan membentuk komunikasi kinerja program yang efektif sehingga akan membuat kondisi kinerja berjalan dengan baik, menjadi lebih mudah, dan program akan terasa ringan untuk direalisasikan bersama.

\section{Simpulan}

Iklim komunikasi organisasi memiliki pengaruh positif terhadap kinerja pengurus, dimana segalanya akan baik jika iklim komunikasinya baik dan begitupun sebaliknya. Oleh karena itu perlu perhatian yang lebih besar dalam hal pengembangan iklim komunikasi organisasi pada UKM HTQ agar semakin baik. Ketua umum perlu banyak mendengarkan berbagai keluhan ataupun masalah yang dihadapi para pengurusnya ketika terjadi kendala dalam kinerja programnya. Dari hasil penelitian tentang unit kegiatan mahasiswa Hai'ah At-Tahfidz Wal-qira'ah, masih perlu peningkatan untuk kinerja program dari semua divisi yang dapat membantu dalam perealisasian program sehingga akan membuat iklim komunikasi dapat meningkatkan kinerja program pengurus lebih tinggi lagi.

\section{Daftar Pustaka}

Hapsari, Elisa Dwi Wulan, and Hamid Arifin. 2016. "Iklim Komunikasi Organisasi Dalam Childhood Cancer Care." 
Jurnal Komunikasi Massa 1. https://www.jurnalkommas.com/docs/ JURNAL_Elisa Dwi Wulan Hapsari_D0211038.pdf.

Keith, Davis, and Jhon W. Newstorm. 2000. Perilaku Dalam Organisasi, Edisi Ketujuh, Alih Bahasa Agus Darma. Jakarta: Erlangga.

Kusumaningrat, Hikmat., and Purnama Kusumaningrat. 2017. Jurnalistik: Teori Dan Praktik. Bandung: PT. Remaja Rosdakarya.

Pace, R. Wayne., and Don F. Faules. 2006. Komunikasi Organisasi: Strategi Meningkatkan Kinerja Perusahaan. Edited by Deddy Mulyana. Bandung: PT. Remaja Rosda Karya Offset.

- 2018. Komunikasi Organisasi. Bandung: PT Remaja Rosdakarya.

Rahmawati, Erna, and Joko Sutarso. 2017. "Pengaruh Iklim Komunikasi Organisasi Terhadap Kinerja Pegawai Pada Bagian Humas Kabupaten Sragen." Universitas Muhammadiyah Surakarta. http://eprints.ums.ac.id/51671/1/JURN AL-erna55.pdf.

Yarosca, Elham Taufandy. 2016. "Pengaruh Pola Komunikasi Organisasi Terhadap Kinerja Karyawan LPP RRI Surakarta." Jurnal Universitas Muhammadiyah Surakarta. http://eprints.ums.ac.id/48538/1/JURN AL.pdf. 